\title{
SARS-COV-2 Vaccines Immunological Impact
}

\author{
Hatem Tallima ${ }^{1,2}$ and Rashika El Ridi ${ }^{1}$ \\ ${ }^{1}$ Zoology Department, Faculty of Science, Cairo University \\ ${ }^{2}$ Department of Chemistry, School of Science and Engineering, American University
}

July 26, 2021

\begin{abstract}
The immune responses to SARS-CoV-2 are herein detailed to clarify the innate immunity protective effects in a large fraction of individuals exposed to the infection, and the drawbacks of the interference of the acquired immunity cytotoxic $\mathrm{T}$ cells and antibody-dependent natural killer cell-mediated cytotoxicity arms. Very precisely, the available vaccines based on full-length spike glycoprotein in a mRNA or DNA-based construct, or whole virus potently lead to generation of these immunologically damaging effectors, especially following exposure to the pathogen. Conversely, a vaccine exclusively based on spike glycoprotein subunit 1 in a protein form can protect against the life-threatening virus infection and never lead to adverse side effects.
\end{abstract}

\section{Hosted file}

SARS-CoV-2 Vaccines.pdf available at https://authorea.com/users/381061/articles/531226-sarscov-2-vaccines-immunological-impact 